\title{
PENERAPAN SAYUR PETIK DENGAN BERBAGAI KEMASAN DI PASAR TRADISIONAL SEBAGAI UPAYA EFISIENSI DISTRIBUSI SAMPAH
}

\author{
Isnaini Nurwahyuni ${ }^{1 *}$, Mizawarti ${ }^{1}$, Hasianna Nopina Situmorang ${ }^{2}$

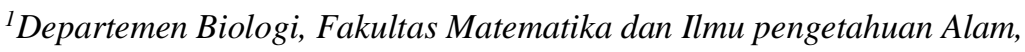 \\ Universitas Sumatera Utara, Medan, Indonesia \\ ${ }^{2} J u r u s a n$ Pendidikan Teknik Mesin, Fakultas Teknik, Universitas Negeri Medan, Indonesia \\ *Penulis korespondensi : isnaininurwahyuni@gmail.com
}

\begin{abstract}
Abstrak
Permasalahan sampah pasar tradisional akibat kegiatan jual beli dipasar memberikan dampak negatif terhadap lingkungan. Sampah pasar yang berupa sisa sayur-sayuran, buah-buahan, dan makanan lainnya adalah bahan yang mudah membusuk dan menghasilkan bau tidak sedap. Masalah ini juga yang dirasakan oleh masyarakat dan pedagang di Pasar Tradisional Setia Kongsi Kecamatan Medan Sunggal, Kota medan. Pemilahan sampah dari sayuran yang diterapkan melalui Kegiatan Pengabdian kepada Masyarakat di pasar ini berupa metode sayur petik yang dikemas menggunakan kotak plastik dan kantong plastik dengan berbagai ukuran. Selain mudah disimpan, sayuran yang dalam keadaan segar dan bersih akan mudah dimasak sehingga menghewat waktu dan tenaga dalam mengolah bahan makanan. Partisipasi aktif dari pedagang sayuran dalam kegiatan pengabdian ini diharapkan dapat mewujudkan pasar menjadi bersih dan tertata dengan baik. Metode ini juga merupakan salah satu cara mengurangi jumlah sampah dari pasar tradisional ke rumah tangga yang sekaligus dapat mengefisiensikan distribusi sampah dalam hal waktu, tenaga dan biaya.
\end{abstract}

Kata Kunci :Sampah, Pasar Tradisional, Sayuran,dan Pemilahan.

\begin{abstract}
The problem of traditional market waste due to buying and selling activities in the market hurt the environment. Market waste in the form of leftover vegetables, fruits, and other food items is perishable and produces an unpleasant odor. This problem is also felt by the community and traders at the Setia Kongsi Traditional Market, Medan Sunggal District, Medan City. The sorting of waste from vegetables that are implemented through Community Service Activities in this market is a method of picking vegetables that are packaged using plastic boxes and plastic bags of various sizes. Apart from being easy to store, vegetables that are fresh and clean will be easy to cook, thereby wasting time and effort in processing food ingredients. It is hoped that the active participation of vegetable traders in these service activities can make the market clean and well ordered. This method is also one way to reduce the amount of waste from traditional markets to households which can also streamline waste distribution in terms of time, effort, and cost.
\end{abstract}

Keywords: Garbage, Traditional Markets, Vegetables, and Sorting.

\section{Pendahuluan}

Sampah merupakan salah satu permasalahan yang dialami masyarakat saat ini. Setiap tahunnya, dapat dipastikan volume sampah akan selalu bertambah seiring waktu akibat pola konsumerisme masyarakat yang semakin meningkat. Kementerian Lingkungan Hidup mencatat rata-rata penduduk
Indonesia menghasilkan $\pm 2,5$ liter sampah per hari atau 625 juta liter dari jumlah total penduduk (Suryani, 2014). Kota Medan yang memiliki luas area $265 \mathrm{~km}^{2}$ dengan jumlah populasi 2.229.408 jiwa menghasilkan timbulan sampah sebesar 1.561 ton /hari (IGES, CCAC-MSW Initiative, 2019). 
Sampah berasal

dari berbagi sumber misalnya dari pasar-pasar tradisional dan modern, pabrik, gerai makanan dari skala kecil hingga besar bahkan dari rumah tangga. Sampah pasar tradisional yang berupa sisa sayuran, buah-buahan, dan makanan lainnya (Triastantra, 2016). Sampah-sampah ini tergolong ke dalam sampah organik yang mudah membusuk dapat menghasilkan bau yang tidak sedap. Keadaan ini akan mencemari lingkungan sehingga perlu penanganan dan pengelolaan dengan baik. Menurut Lukas (2011) sebagian besar sampah pasar tradisional masih dapat diolah menjadi barang yang berguna seperti untuk pembuatan kompos.

Menurut Undang-undang Nomor 18 Tahun 2008 tentang Pengelolaan Sampah serta Peraturan Pemerintah Nomor 81 tahun 2012 mengamanatkan perlunya perubahan paradigma yang mendasar dalam pengelolaan sampah yaitu dari paradigma angkutbuang, menjadi pengelolaan yang bertumpu pada pengurangan sampah dan penanganan sampah (Suryani, 2014). Pasar yang masih menerapkan sistem angkut-bunag adalah pasar tradisional Setia Kongsi, Medan. Pasar ini beroperasi mulai dari pagi hari jam 6.00 wib hingga jam 18.00 wib sore.

Di pasar Setia Kongsi ini banyak ditemukan pedagang sayur-sayuran. Para pedagang menjajakan dagangan dengan berbagai cara yaitu meletakkan sayuran dipinggir-pinggir jalan dengan beralaskan terpal atau plastik; ada yang meletakkannya di dalam keranjang atau baskom dan ada yang menggunakan meja untuk menyusun sayuran serta ada berjualan sayuran ditoko. Kondisi berjualan yang dekat ke badan jalan menyebabkan sayuran yang dijual kurang terjamin kebersihannya sehingga sangat membahayakan bagi kesehatan konsumen.

Sebagian dari pedagang menjajakan jualannya tanpa pelindung/atap sehingga sayuran langsung terkena sinar matahari sehingga mudah layu dan tidak tahan lama. Ini akan merugikan pedagang sayuran sendiri karena sayuran yang layu akan mengurangi kesegaran atau kwalitas sehingga kurang atau tidak diminati oleh pembeli. Hal ini harus diperhatikan bagi pedagang, sebagaimana yang dinyatakan oleh Yuarini et al. (2015) bahwa beberapa atribut mutu yang merupakan keinginan dan harapan tertinggi dari konsumen yang harus dipenuhi terhadap kualitas sayuran diantaranya adalah kebersihan, kesegaran, keamanan pangan, daya tahan, warna, ukuran dan bentuk dari sayuran terseebut.

Disamping itu, pedagang menjual sayuran masih dalam keadaan utuh yaitu masih menyertakan bagian yang tidak bisa dikonsumsi seperti akar, batang, tangkai daun dan sebagainya. Bagian-bagian ini ikut terbawa oleh pembeli dan akan menambah jumlah sampah sayuran yang terdistribusi ke rumah tangga. Oleh karena itu, diperlukan suatu sistem pengolahan sampah sayuran yang mudah diterapkan dan berguna baik terhadap pedagang maupun pembeli. Metode yang sederhana berupa sayur petik yang dikemas dalam berbagai bentuk kemasan diharapkan dapat memberikan hasil yang optimal dalam mengolah dan mengendalikan limbah rumah tangga sehingga berdampak positif terhadap lingkungan.

\section{METODE}

\section{A. Metoda Pendekatan :}

Metode yang dipilih untuk penyampaian materi adalah dengan penyuluhan. Penyuluhan yang diberikan adalah tentang manfaat manjaga kebersihan bahan makanan secara umum dan khususnya sayuran. Pada penyuluhan juga disampaikan bagaimana menyiapkan barang dagangan berupa sayuran menjadi kemasan yang bersih, lebih tahan lama (tidak mudah layu) dan menarik. Disamping itu, pada penyuluhan ini juga memberikan inovasi untuk mengembangkan kewirusahaan sayuran. Metode pendekatan dilakukan dalam 2 (dua) cara yaitu :

\section{Ceramah}

Memberikan pemahaman kepada pengelola pasar dan para pedagang tentang kebersihan yang ada dilingkungan sekitar dan masalah yang sering dihadapi terutama mengenai sampah, seperti sampah dari sayuran serta manfaat apa yang bisa diperoleh dari sampah sayuran. Materi yang disampaikan juga bagaimana mengatasi masalah sampah sayuran yang terdapat di pasar-pasar tradisional. Salah satu cara adalah dengan pemilahan sayuran antara bagian yang bisa diolah dengan bagian yang akan menjadi sampah dan selanjutnya disiapkan dalam kemasaan yang bersih dan menarik.

\section{Praktek}

Pada metode ini, tim pengabdian menyampaikan cara dan memberikan contoh pemilahan sayuran seperti daun, batang dan akar. Para pedagang sayuran diminta mempraktekkan bagaimana cara melakukan pemilahan sayuran untuk bermacam-macam jenis sayuran yang diperjulbelikan. Setelah itu, diperagakan alat-alat kemasan apa saja yang bisa digunakan untuk sayuran dan bagaimana cara pembuatan kemasan untuk bermacammacam sayuran.

\section{B. Alat dan Bahan:}


Alat yang digunakan adalah berupa telenan, Pisau, Timbangan, Baskom, Box besar, alat-alat kemasan terdiri dari plastik, kotak plastik dan kantong plastik assoy, kliper, spidol, karet dan kertas label harga.

Bahan yang pakai adalah bermacam-macam sayuran yang teridiri dari kangkung, bayam, kol, brokoli, kacang panjang, toge, sawi manis, sawi putih, sawi pahit, cabai merah, cabai hijau, cabai rawit, bawang merah, bawang putih, daun singkong dan pakis. Es balok digunakan untuk menjaga kesegaran sayuran dengan cara diletakkan pada wadah/ tempat sayur kamasan.

\section{Prosedur kerja :}

\section{Penyiapan sayuran}

Sayur-sayuran yang akan digunakan pada pengabdian ini diperoleh dari pedagang sayuran di pasar tradisional Setia Kongsi, yang mana bentuk sayuran masih dalam keadaan utuh dan segar. Setiap jenis sayuran diletakkan dalam masing-masing baskom yang berbeda dan diberi nama.

\section{Pemilahan sayuran}

Setiap jenis sayuran diambil dan diamati bagian mana yang akan dipilahatau dipisahkan antara bagian yang baik untuk diolah dengan bagian sampah. Kemudian dilakukan pemotongan dan ditempatkan dalam baskom yang berbeda. Cara ini dilakukan untuk semua jenis sayuran yang disiapkan dan didapatkan hasil sayuran yang sudah dipotong-potong.

\section{Pengemasan sayuran}

Sayuran yang sudah dipotong-potong selanjutnya ditimbang sesuai dengan besar kemasan yang akan dijual. Setelah ditimbang, sayuran potong dimasukkan ke dalam kemasan yang sesuai dengan beratnya. Bentuk kemasan ini ada yang berbentuk kotak dan kantong yang berklep serta kantong plastik biasa. Kotak plastik yang digunakan berukuran $500 \mathrm{ml}, 750$ $\mathrm{ml}$ dan $1000 \mathrm{ml}$. Bila menggunakan kantong plastik biasa, kemasan harus diikat dengan karet agar terlihat rapi dan diberi lubang pada bagian permukaannya untuk sirkulasi udara.

\section{Pembuatan label harga}

Sayuran dalam kemasan yang telah siap diberi label harga dengan cara menempelkan kertas label yang telah ditulis terlebih dahulu. Cara ini dilakukan agar memudahkan para pembeli untuk mengenali harga sayuran yang diperjualbelikan dan membantu pembełkndukias pedagang dirasakan sangat tinggi dalam kegiatan ini. Hal ini dapat dilihat dari keinginan mereka untuk mencoba atau mempraktekkan cara menentukan pilihan berat dan harga sayuran yang dibutuhkannya.

5. Penyiapan sayuran kemasan untuk dijual Sebelum sayur kemasan dijual, terlebih dahulu dimasukkan dan disusun dalam suatu box besar yang telah diberi es balok. Selanjutnya disiapkan wadah atau tempat yang bersih berupa meja-meja yang cukup tinggi agar tidak mudah terkena kotoran yang ada dijalan atau lorong gang di pasar tersebut.

\section{Pemantauan dan Evaluasi}

Untuk mengetahui sejauh mana penerapan metode sayur petik oleh pedagang sayuran dilakukan pemantauan selama 2 bulan. Pada waktu pemantauan juga dilakukan kuisioner kepada pembeli untuk mendapatkan gambaran bagaimana tanggapan mereka terhadap sayur petik. Hasil dari pemantauan dilakukan evaluasi.

\section{HASIL DAN PEMBAHASAN}

\subsection{Waktu Pelaksanaan}

Pelaksanaan pengabdian telah dilakukan pada hari Sabtu, tanggal 29 Agustus 2020 di Pasar Setia Kongsi yang berada di Jalan Setia Budi Gg. Mawar Kelurahan Tanjung Rejo, Kecamatan Medan Sunggal. Pasar Setia Kongsi merupakan salah satu pasar tradisional yang selalu ramai dikunjungi oleh masyarakat disekitar untuk memenuhi kebutuhan sehari-hari terutama untuk kebutuhan dapur.

\subsection{Penyajian Materi Dan Penyuluhan}

Kegiatan ini dihadiri langsung oleh Pengelola Pasar Setia Kongsi, Bapak Izul Malem Ginting dan dibantu oleh beberapa mahasiswa serta pegawai di Departemen Biologi Fakultas Matematika dan Ilmu Pengetahuan Alam Universitas Sumatera Utara. Jumlah pedagang yang mengikuti kegiatan.

Acara diawali dengan pembukaan sambutan kegiatan penyuluhan oleh Ketua Pelaksana. Kemudian ketua pelaksana dan tim pengabdian mulai menyampaikan materi dan penyuluhan kepada setiap pedagang sayur dengan cara mendatangi satu per satu. Pengetahuan yang akan diberikan kepada mitra "para pedagang sayuran di Pasar Tradisional Pasar Pagi Setia Budi "Setia Kongsi” anatara lain :

1. Pentingnya menjaga kebersihan sayuran di pasar

2. Manfaat memilah sayuran untuk diperjualbelikan

3. Teknik pemilahan bermacam-macm sayuran yang banyak dikonsumsi

4. Teknik pengemasan sayuran

5. Cara menata dagangan sayuran agar tetap segar

6. Cara mempromosikan manfaat berbelanja sayuran kemasan kepada pembeli. 


\section{J}

menyiapkan sayuran akan Disini tim pengabdian memberikan contoh sayur kemasan dan kan bantuan bahan-bahan yang diperlukan untuk mengemas sayurAdapun kegiatan penyuluhan dan praktek ke pedagang dapat dilihat ambar 1 . berikut ini.

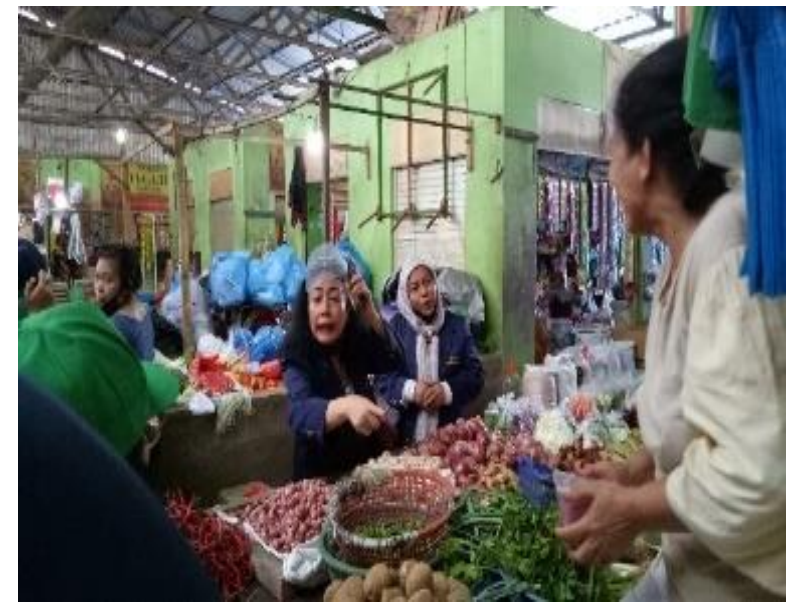

Untuk menarik minat pembeli setiap pedagang diberi logo Menjual "Sayur Petik" (Gambar 2.) sehingga memudahkan bagi pembeli mengenali pedagang sayuran yang menjual sayuran yang sudah siap dimasak. Logo ini berguna sebagai informasi

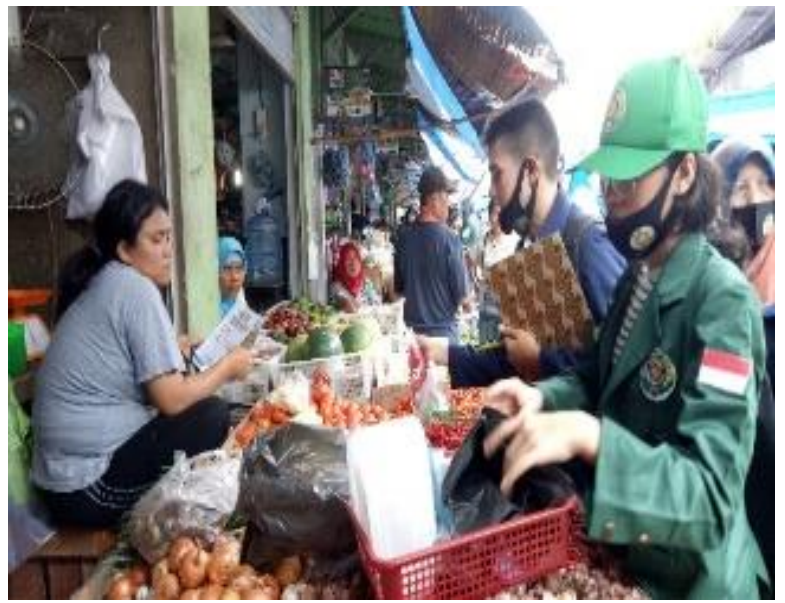

Gambar 1. Penyuluhan dan Praktek Sayur Petik

\section{MENJUAL "SAYUR PETIK" \\ - segar - bersih \\ - mutu terjamin - harga terjangkau}

\section{NOTE: MENERIMA PEMESANAN DALAM "PARTAI BESAR"}

\section{Gambar 2. Bentuk Logo "Sayur Petik"}

bahwa telah ada dijual sayur yang sudah dipetik dan dikemas dengan baik di pasar tradisional Setia Kongsi ini. Kemasan yang digunakan adalah berbahan dasar plastik. Kegunaan dari kemasan dalam bentuk ini adalah pertama, tampilan sayuran akan tampak bersih dan rapi karena plastik berbentuk transparan sehingga isi sayuran jelas terlihat dan

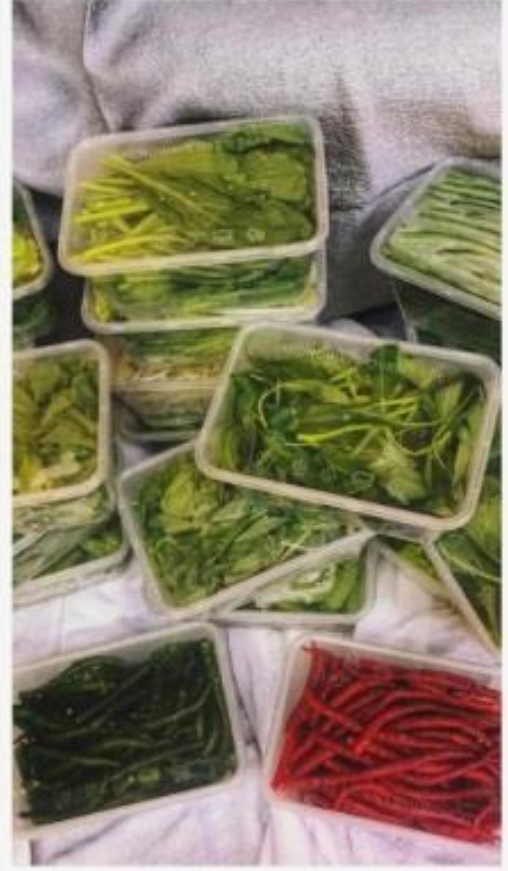

PENGABDIAN KEPADA MASYARAKAT USU 2020 
Tabel 1. Berat sayur, berat sampah dan waktu yang diperlukan untuk memetik sayuran.

\begin{tabular}{|c|c|c|c|c|c|}
\hline No. & Jenis sayuran & $\begin{array}{l}\text { Berat awal } \\
\text { (gram) }\end{array}$ & $\begin{array}{l}\text { Berat sisa/sampah } \\
\quad \text { (gram) }\end{array}$ & $\begin{array}{l}\text { Berat bersih } \\
\quad \text { (gram) }\end{array}$ & $\begin{array}{l}\text { Waktu petik } \\
\text { (.. menit .. detik) }\end{array}$ \\
\hline 1 & Bawang merah & 250 & 13,67 & 236,33 & 6 menit 36 detik \\
\hline 2 & Bawang putih & 250 & 10,33 & 239,67 & 17 menit 19 detik \\
\hline 3 & Bayam & 250 & 131,00 & 119,00 & 3 menit 34 detik \\
\hline 4 & Brokoli & 250 & 109,00 & 141,00 & 1 menit 26 detik \\
\hline 5 & Bunga kol & 250 & 105,33 & 144,67 & 2 menit 25 detik \\
\hline 6 & Cabe hijau & 250 & 18,00 & 232,00 & 2 menit 53 detik \\
\hline 7 & Cabe merah & 250 & 18,00 & 232,00 & 3 menit 7 detik \\
\hline 8 & Cabe rawit & 250 & 27,33 & 222,67 & 8 menit 29 detik \\
\hline 9 & Daun singkong & 250 & 143,67 & 106,33 & 2 menit 31 detik \\
\hline 10 & Kangkung & 250 & 126,67 & 123,33 & 4 menit 6 detik \\
\hline 11 & Kol & 250 & 65,67 & 184,33 & 2 menit 8 detik \\
\hline 12 & Pakis & 250 & 126,67 & 123,33 & 5 menit 10 detik \\
\hline 13 & Sawi botol & 250 & 71,33 & 178,67 & 1 menit 24 detik \\
\hline 14 & Sawi manis & 250 & 79,33 & 170,67 & 2 menit 10 detik \\
\hline 15 & Sawi pahit & 250 & 35,67 & 214,33 & 1 menit 2 detik \\
\hline 16 & Sawi putih & 250 & 16,00 & 234,00 & 1 menit 43 detik \\
\hline 17 & Toge & 250 & 29,67 & 220,33 & 22 menit 41 detik \\
\hline
\end{tabular}

Tabel 1. diatas memperlihatkan waktu petik dan berat sampah sayuran yang terbuang dari bermacam-macam sayuran. Berapa waktu yang akan dihemat dapat diketahui dari waktu yang diperlukan untuk memetik sayuran tersebut seperti sayur toge dan mengupas bawang putih membutuhkan waktu yang cukup lama berturut-turut sekitar 22 menit dan 17 menit. Ada beberapa jenis sayuran yang berat sampahnya lebih dari $1 / 2$ berat total sayur tersebut seperti sayur bayam, daun singkong, kangkung dan Pakis.

Untuk membantu pemahaman kepada konsumen, dijelaskan beberapa manfaat yang akan diperoleh dengan tersedianya sayur petik ini adalah :

1. membeli sayuran yang sudah bersih

2. membeli sayuran yang sudah dipotong

3. membeli sayuran yang segar

4. sayuran mudah disimpan di dalam kulkas

5. menghemat tenaga

6. menghemat waktu

7. mengurangi sampah rumah tangga.

Ditambahkan juga bahwa dari pengemasan sayur petik tersebut ada bagian dari sayur yang tersisa tidak dibutuhkan dalam memasak dan akan menjadi sampah. Sejumlah sampah yang biasa dibawa ke rumah akan tinggal di pasar. Selanjutnya sampah sayuran ini dapat dimanfaatkan oleh masyarakat yang membutuhkan untuk digunakan sebagai pakan ikan dan ternak atau dimanfaatkan dalam pembuatan kompos. Selain itu juga dapat mengurangi jumlah sampah di rumah tangga. Jumlah sampah yang berkurang akan mengurangi jumlah distribusi sampah ke Tempat Pembuangan Sampah (TPS).

\subsection{Sesi Diskusi dan Tanya Jawab}

Selain memberikan penyuluhan dan cara mempraktekkan penyiapan sayur petik, kegiatan ini juga diikuti dengan diskusi dan tanya jawab. Pada Gambar 3. terlihat hasil dari para pedagang mempraktekkan cara menyiapkan sayur petik. Untuk mengetahui pemahaman berbagai aspek tentang manfaat metode ini bagi masyarakat dilakukan pengisian kuisioner kepada 19 orang pedagang. Hasil kuesioner dapat dilihat pada Grafik 1.

Pada sesi tanya jawab ini, pedagang sayuran sangat antusias bertanya. Dari hasil tanya jawab didapat gambaran bahwa sudah ada beberapa pedagang yang sudah menjual sayur petik dalam dagangannya, namun tidak memiliki ide untuk pengemasan barang dagangannya tersebut. Pedagang mengaku sulit dan ragu menggunakan kemasan plastik karena akan menambah harga sayuran dari pada berjulan secara langsung. Disamping itu, karena keterbatasan tenaga untuk mengerjakannya membuat pedagang belum begitu yakin akan menerapkan metode ini. Namun ada beberapa pedagang yang berminat akan melakukan cara ini dan 
diperoleh dua pedagang yang bersedia untuk dilakukan pemantauan. Seperangkat peralatan dan kemasan diberikan kepada pedagang ini untuk memudahkan menerapkan metode sayur petik tersebut. Hal ini diharapkan akan berdampak pada peningkatan omset penjualan bagi pedagang sayuran.

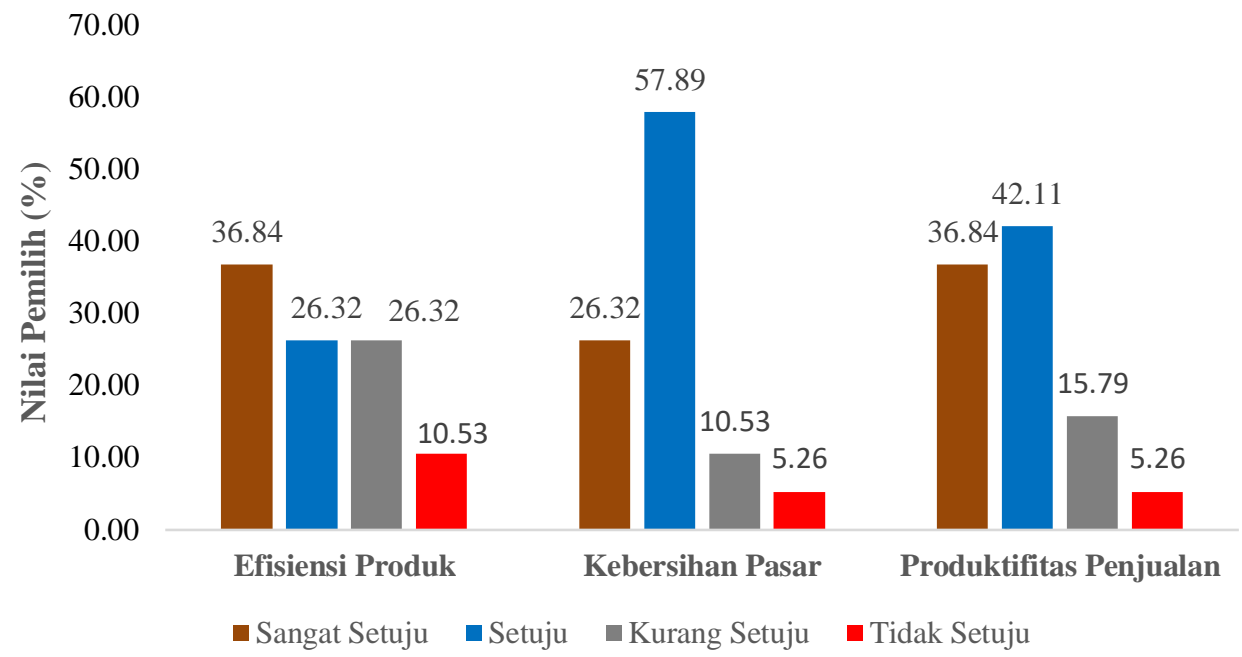

Grafik 1. Respon pedagang terhadap penerapan sayur petik di pasar tradisional
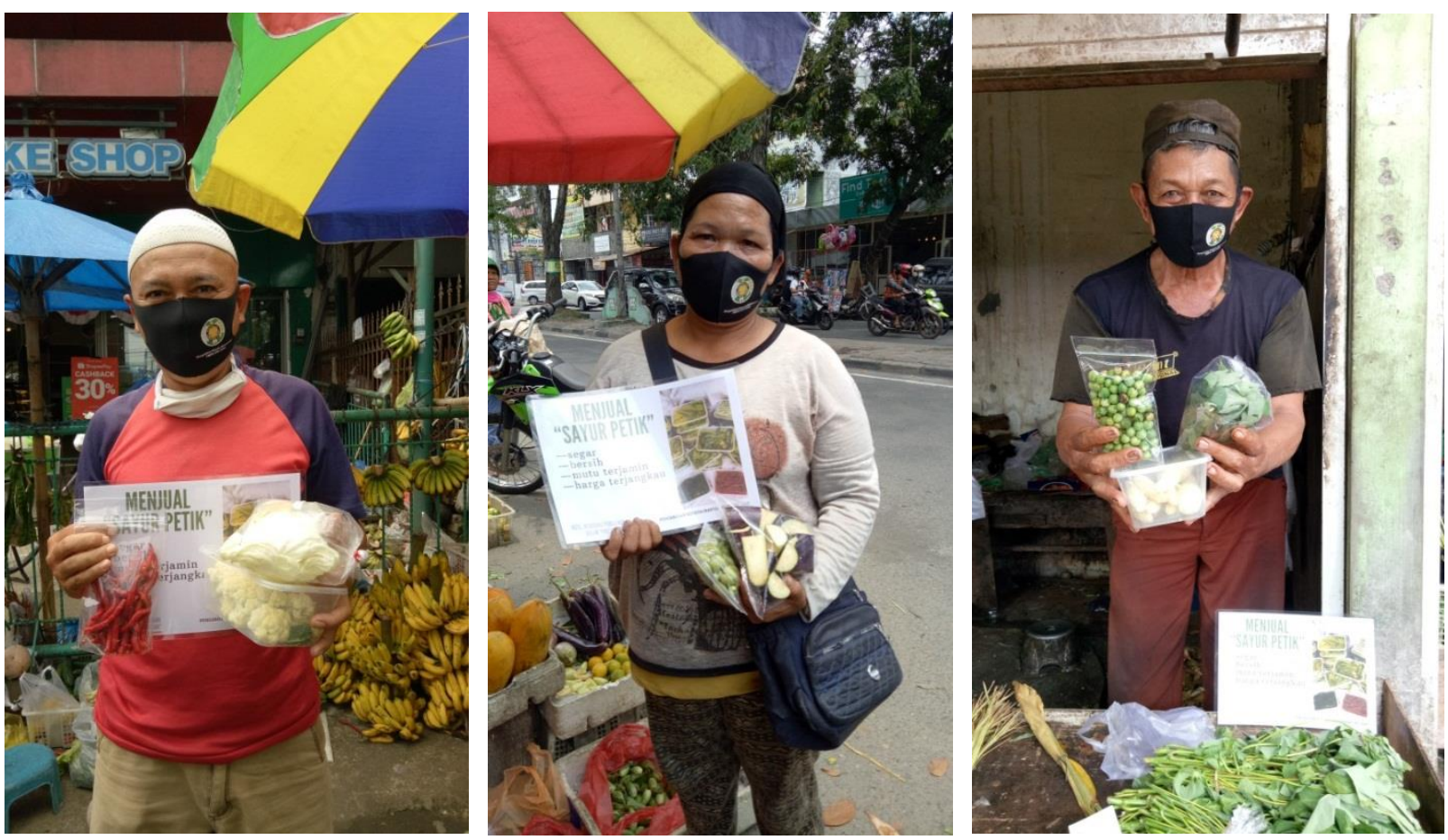

Gambar 3. Para pedagang dengan sayur petik

Berdasarkan Grafik 1. dapat diketahui dari 19 responden yang memberikan tanggapan terlihat $36,84 \%$ yang sangat setuju mengenai efisiensi produk, selebihnya sejutu $26,32 \%$ dan kurang setuju juga $26,32 \%$ serta tidak sejutu $10,53 \%$. Hal ini menggambarkan bahwa total pedagang yang sangat setuju dan setuju jika produk ini efisien mencapai kisaran angka $63 \%$ dan total yang kurang dan tidak setuju sekitar $37 \%$. Demikian juga untuk total respon pedagang terhadap kebersihan pasar dan produktifitas penjualan yang sangat setuju dan setuju menunjukkan angka berturut-turut adalah $84 \%$ dan $79 \%$. Angkaangka ini menunjukkan para pedagang sebagian besar menyukai kemasan sayur petik ini.

\subsection{Hasil Pemantauan}

Untuk mengetahui perkembangan penerapan metode sayur petik ini kepada pedagang yang telah dipilih pada waktu pelaksanaan pengabdian, maka 
dilakukan pemantauan selama dua bulan yaitu dari bulan September hingga Oktober 2020. Dari hasil wawancara diketahui bahwa metode ini telah mulai diterapkan oleh pedagang dan telah berusaha menawarkan bentuk kemasan sayuran kepada pembeli. Namun, belum banyak jenis sayuran yang disediakan karena peminat yang membeli sayuran ini masih sedikit. Hal ini disebabkan karena mereka belum terbiasa belanja dengan bentuk sayur yang sudah dipetik dan masih ada kekhawatiran karena tidak bisa memastikan banyak sayur yang dibeli apabila dalam keadaan yang telah dipetik serta daya tahan sayuran selama penyimapan. Untuk mengatasi hal ini tentu membutuhkan usaha dan waktu untuk meyakinkan pembeli sehingga mereka bisa merasakan manfaat berbelanja sayur petik ini.
Berdasarkan hasil kuisener yang diberikan kepada 20 orang pembeli yang berperan sebagai responden dapat diketahui bahwa sekitar 20-40\% yang memberikan respon setuju terhadap pernyataan yang diberikan baik terhadap bentuk kemasan berpengaruh terhadap minat untuk membeli dan kualitas dan harga. Hal ini menunjukkan responden tidak sepenuhnya memahami tentang sayur petik sehingga perlu sosialisasi lebih lanjut. Namun ada sekitar $75 \%$ yang memberikan respon yang netral terhadap kesesuaian harga sayur kemasan dengan manfaat. Angka ini juga menunjukkan bahwa pembeli sebagian besar belum bisa memutuskan masalah harga dan hanya menyerahkankan sepenuhnya kepada pedagang. Selain itu, pembeli belum bisa merasakan manfaatnya karena produk ini baru dan belum pernah membelinya.

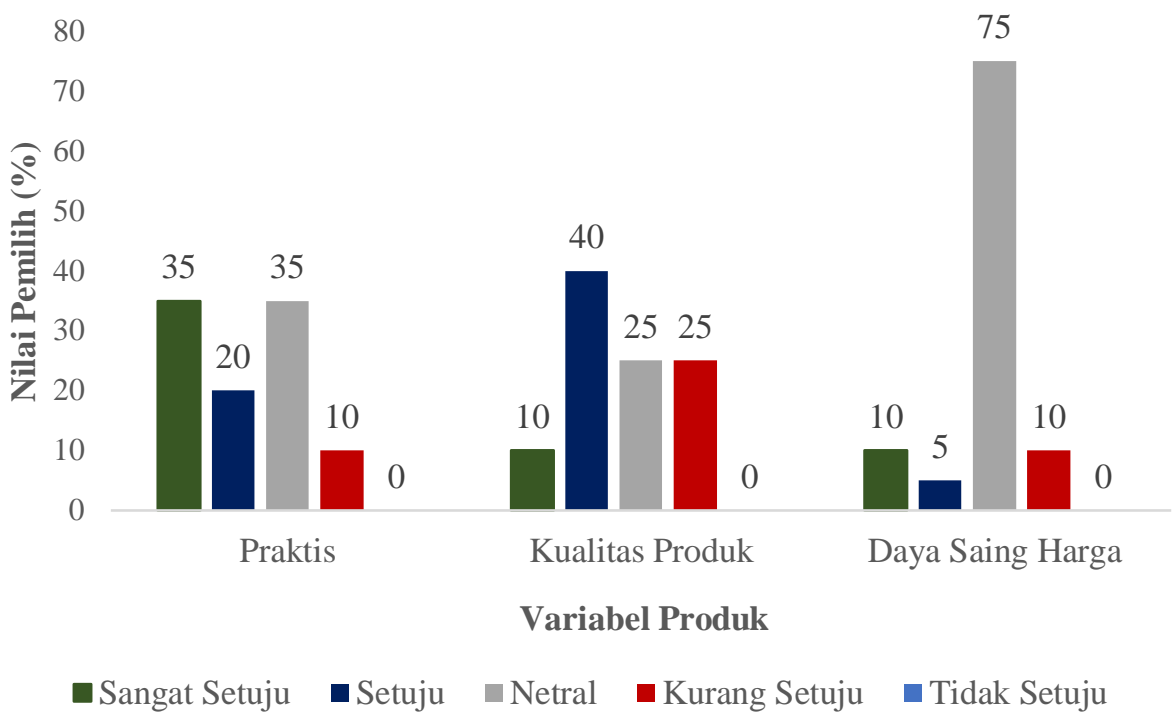

Grafik 2. Respon konsumen terhadap penerapan sayur petik di pasar tradisional

Respon dari konsumen dapat dilihat pada Grafik 2. menggambarkan angka yang berbeda bahwa sebagian kecil yang menyukai sayur petik ini. Hal ini terlihat dari masih rendahnya nilai respon terhadap praktis kemasan sayuran ini yaitu hanya $30 \%$ yang sangat setuju dan $20 \%$ saja yang setuju. Ini berarti total konsumen yang menyukai hanya $50 \%$ saja. Demikian juga pada opsi kualitas produk dan daya saing harga berturut-turut nilai total yang sangat setuju dan setuju yaitu $50 \%$ dan $15 \%$.

Masalah yang akan ditimbulkan dengan penggunaan kemasan plastik ini adalah akan banyak sampah plastik yang akan dibawa oleh pembeli atau diangkut ke rumah tangga. Namun begitu jenis sampahnya akan mudah dikelola karena sampah tidak banyak tercampur dengan sampah organik dan jumlah sampah yang diangkut dari rumah tangga akan berkurang dengan sendirinya. Hal ini akan berdampak kepada pengurangan biaya dalam pengangkutan ke Tempat Penampungan Sementara (TPS) dan sangat menguntungkan bagi pemerintah daerah setempat. Menurut Pemerintah Kota Medan, (2013) bahwa penanganan sampah ditekankan pada rangkaian kegiatan yang mencakup pemilahan (pengelompokan dan pemisahan sampah menurut jenis dan sifatnya), pengumpulan (memindahkan sampah dari sumber sampah ke TPS atau tempat pengolahan sampah terpadu).

\section{Kesimpulan}

Ada beberapa kesimpulan yang dapat diambil dari pelaksanaan pengabdian kepada masyarakat ini yaitu:

1. Penyuluhan tentang "Sayur Petik" diharapkan dapat menambah wawasan serta meningkatkan 
$\begin{array}{llr}\text { omset } & \begin{array}{r}\text { pedagang } \\ \text { dibandingkan saran } \\ \text { dengan } \\ \text { konvensionalan }\end{array} & \end{array}$

2. Hampir seluruh jenis sayuran dapat diaplikasikan dengan metode "Sayur Petik" diantaranya: brokoli, kembang kol, saw manis, sawi putih, sawi pahit, wortel, bawang, cabai dan lain-lain.

3. Metode "Sayur Petik" diharapkan dapat memutus mata rantai sampah organik hasil pemilahan sayuran dari pasar-pasar tradisional ke rumah tangga.

4. Untuk mewujudkan kebersihan pasar-pasar tradisional masih perlu sosialisasi kepada masyarakat tentang manfaat sayur petik.

\section{Ucapan Terima Kasih}

Penulis mengucapkan terima kasih kepada Universitas Sumatera Utara, Medan yang telah memberikan bantuan pembiayaan yang berasal dari NON PNBP (Nomor: 287/UN5.2.3.2.1/PPM/2020) untuk pelaksanaan kegiatan pengabdian kepada masyarakat di bawah Skema Mono Tahun Reguler. Terima kasih khusus kepada para mahasiswa dan pegawai yang terlibat dalam kelancaran kegiatan ini.

\section{DAFTAR PUSTAKA}

IGES, CCAC-MSW Initiative (2019) Rencana Kerja Penurunan Emisi SLCP dari Pengelolaan Limbah Padat Perkotaan di Kota Medan, Indonesia 2019 - 2025. Institute for Global Environmental Strategies.
Lukas, 2011. Studi Pengelolaan Sampah Organik di IPSO Pasar Cisarua Kabupaten Bogor. Media SainS, 3 (1):33-39.

Pemerintah Kota Medan, 2013. Laporan Akhir. Kajian Model Pengelolaan Sampah dan SDM Kebersihan dI Kota Mrdan. Provinsi Sumatera Utara, Medan.

Rahayu, D.E. and Yudi Sukmono. 2013. Kajian Potensi Pemanfaatan Sampah Organik Berdasarkan Karakteristiknya. Jurnal Sains dan Teknologi Lingkungan. 5(2): 77-90.

Suryani, A.S., 2014. Peran Bank Sampah Dalam Efektivitas Pengelolaan Sampah (Studi Kasus Bank Sampah Malang). Aspirasi. 5(1): 71-72

Triastantra, M., 2016. Pengelolaan Sampah Pasar Sebagai Upaya Pengendalian Pencemaran Lingkungan Berdasarkan Peraturan Daerah Kota Yogyakarta Nomor 10 Tahn 2012 Tentang Pengelolaan Sampah (Studi Kasus Di Pasar Giwangan Kota Yogyakarta). Jurnal ilmiah. Universitas Atma Jaya Yogyakarta. 5(1): 80.

Yuarini, D.A.A., I Ketut Satriawan and I Dewa. P.O. Suardi (2015). Jurnal Manajemen Agribisnis. 3(1):93-109. 